Chirurgia (2019) 114: 753-760

No. 6, November - December

Copyright $\odot$ Celsius

http://dx.doi.org/10.21614/chirurgia.114.6.753

\title{
Excellent Short- and Medium-term Result of Bariatric Surgery in Adolescence. A Single Center Study
}

\author{
Daniela Dobritoiu', Maura Buza', Elena Catanescu', Catalin Copaescu ${ }^{1}, 2$ \\ 'Ponderas Academic Hospital Bucharest, Romania \\ 2"Grigore T Popa" University of Medicine and Pharmacy, Iasi, Romania
}

Corresponding author:

Catalin Copaescu, MD PhD

Associated Professor of Surgery

Ponderas Academic Hospital

Nicolae Caramfil Street, no. 85 A

district 1, Bucharest, Romania

E-mail: catalin.copaescu@ponderas-ah.ro
Received: 10.11 .2019

Accepted: 19.12 .2019

\section{Rezumat \\ Rezultate excelente pe termen scurt și mediu ale chirurgie bariatrice la adolescenti. Un studiu unicentric}

Background: Obezitatea la copil este o problemă cu care ne confruntăm din ce în ce mai des. Deşi chirurgia metabolică aplicată copiilor a fost inițial privită cu scepticism, numărul articolelor ştiințifice care abordează această problemă şi susțin intervenția cât mai rapidă este deja coniderabil. Cu toate acestea există, încă multe controverse legate de indicația de intervenție chirurgicală şi rezultatele pe termen lung la aceşti pacienți.

Scop: Analizarea rezultatelor chirurgiei bariatrice la un grup de adolescenți cu obezitate operați în spitalul nostru.

Metoda: Am analizat retrospectiv datele tuturor pacienților adolescenți cu obezitate care au fost operați - gastrectomie longitudinală laparoscopică sau gastric by pass în perioada 2013noiembrie 2019 într-un Centru de Excelență în Chirurgia Bariatrică, urmărind prezența preoperator a comorbidităților legate de obezitate, evoluția BMI şi a comorbidităților la 12 şi 36 luni postoparator.

Rezultate: Şaizeci şi patru de pacienți au fost incluşi în studiu, 62 cu gastrectomie longitudinală (SG) şi doi cu bypass gastric (GBP). Vârsta medie la momentul operator a fost de 15 ani şi 5 luni (SD 18 luni). Indexul BMI mediu înainte de operatie a fost $39.45 \mathrm{~kg} / \mathrm{m}^{2}$ (SD 6.9) şi a scăzut la $24.92 \mathrm{~kg} / \mathrm{m}^{2}$ şi $22.7 \mathrm{~kg} / \mathrm{m}^{2}$ la 12 respectiv 36 de luni de la intervenție. $\mathrm{Nu}$ s-au înregistrat complicații majore perioperatorii, consemnând doar un caz de disfagie prelungită, tranzitorie postoperator. Durata medie de spitalizare a fost de 3.2 zile. În primul an de monitorizare postoperatorie s-au înregistrat doar complicații minore, ce au putut fi controlate medical: anemie 
(6/61), deficit de folați (5/61), constipație (22/61), căderea părului (12/61).

Concluzii: Chirurgia bariatrică şi metabolică este sigură şi eficientă în tratamentul obezității la adolescent, atunci când este efectuată în centre cu experiență.

Cuvinte cheie: obezitate infantilă, adolescenți, chirurgie bariatrică, rezecție gastrică

\section{Abstract}

Background: Childhood obesity is becoming more frequent and the age of diagnosis has decreased. Although initially sceptic about bariatric surgery in children and adolescents the number of papers to advocate earlier bariatric interventions in this age group is now considerable. However, there are still a lot of controversies about bariatric surgery's indications and long-term results in these patients.

Aim/Objective: To analyze the outcomes of bariatric surgery in a group of adolescents with obesity operated in our hospital.

Methods: We analyzed retrospectively all the consecutive adolescent patients who underwent laparoscopic gastric sleeve or gastric bypass between 2013 and November 2019 in a Bariatric Center of Excellence, tracking the perioperative morbidity, the changes of BMI and comorbidities at 12 and 36 PO months.

Results: Sixty-four adolescent patients were included in the study, 62 with sleeve gastrectomy (SG) and two with gastric bypass (GBP). Mean age at operation was 15 years and 5 months (SD 18 months). Mean BMI before operation was $39.45 \mathrm{~kg} / \mathrm{m}^{2}$ (SD 6.9) and decreased to $24.92 \mathrm{~kg} / \mathrm{m}^{2}$ and $22.7 \mathrm{~kg} / \mathrm{m}^{2}$ by 12 and 36 months respectively. There were no major perioperative complications, but early transitory postoperative dysphagia in one case. The mean length of hospital stay was 3.2 days. Mild, medically manageable complications were encountered in the first postoperative year: (anemia (6/61), folate deficiency (5/61), constipation (22/61), temporary hair loss (12/61).

Conclusions: Bariatric surgery is safe and effective in treating adolescent obesity, when preformed in experienced centers.

Key words: childhood obesity, adolescents, bariatric surgery, gastric sleeve

\section{Introduction/Background}

Obesity is a chronic disease and it has been recognized as such since 2002 (1). It is multifactorial caused by a combination of genetics, environment and metabolic programming. (2) Most of the times it is determined by an imbalance between the calories ingested and energy expenditure but some medical conditions are also known to determine excessive fat accumulation (Prader Willy Syndrome, Cushing Syndrome, different medications).

Overweight and obesity in children, same as in adults, are strongly associated with risk factors for cardiovascular diseases as well as type 2 diabetes, obstructive sleep apnea, renal disease, orthopedic problems, polycystic ovarian syndrome, eating disorders and low self-esteem. Some of these patients also face poor social relationships that adds to a low quality of life. Moreover, the overweight child has a great risk of being overweight or obese as an adult with an increased risk of earlier development of cardiovascular disease and a high rate of mortality. (3) Higher mortality throw cancer and higher incidence of some cancer types have also been documented in obese patients (4).

All over the world papers report alarming increase of childhood and adolescent obesity, as defined by the World Health Organization $\left(B M I>95^{\text {th }}\right.$ percentile for age and sex for the 
obese adolescent and BMI $>120 \%$ of the $95^{\text {th }}$ percentile or $\mathrm{BMI} \geq 35 \mathrm{~kg} / \mathrm{m}^{2}$, whichever is lower, for the severely obese) (5).

In Romania, although the rate of adolescent obesity remains lower than the mean rate in the European Union, rates have doubled within the past ten years, form $7 \%$ in $2006-2007$ to $14 \%$ in 2013-2014 (3).

It is true that prevention is the mainstay in the fight against obesity and this means to encourage a healthy lifestyle with constant balanced diet and moderate physical activity. Still, the intense application of nonsurgical treatment modalities - radical behavior shift and diet change - in the obese and extremely obese adolescents has only proven to have unsatisfactory and short term results, while bariatric and metabolic surgery emerges as the most effective treatment option $(6,7,8,9)$.

Until recently, the bariatric procedures accepted in pediatric patients were gastric bypass and gastric banding, but lately gastric sleeve gained more and more confidence (10). Multiple studies suggested that laparoscopic sleeve gastrectomy (LSG) should be performed in obese adolescents due to its low rate of complication, good results in losing excess weight and maintaining the physiologic sequence of the digestive tube segments (11). Even when compared to adults, LSG seems to be more efficient in adolescents in treating obesity related complications like glucose intolerance and type 2 diabetes (12).

There are now several consensus and guidelines for the management of pediatric and adolescent obesity $(13,14)$. Last year, the pediatric committee of The American Society for Metabolic and Bariatric Surgery published new guidelines, as an update to those published in 2012, and admitted that bariatric and metabolic surgery should be considered earlier in the treatment of obese and extremely obese adolescents with cardiovascular disease, type 2 diabetes or other obesity related complications, while mental health problems, or inferior Tanner stage should not be considered contraindications, but should warrant very close follow-up (15)

In this context it is imperative that primary care physicians should identify overweight and obese children so that counseling and treatment can be provided. Those with already installed end-organ diseases or those in whom medical treatment was not proven successful, warrant referral to pediatric obesity centers, where multidisciplinary teams are necessary for appropriate dietary, psychologic, pharmacologic, and/or surgical therapy. However, a complete initial evaluation and close, long term follow up are essential for best results.

Adolescents and children were included in the bariatric surgery program run in Ponderas Academic Hospital since 2011 and encouraging results were noted. Although pediatric and adolescent obesity has increased in Romania, as is has all over the world, literature about surgical treatment of this patients in our country scarce.

The aim of the present study was to analyze the outcomes of bariatric surgery in a group of adolescents with obesity operated in our hospital. The results and the post operatory evolution of adolescents with obesity who underwent bariatric surgery procedures sleeve gastrectomy and gastric bypass in our center were assessed.

\section{Material and Method}

We retrospectively analyzed available data from all consecutive adolescents who received metabolic surgery in Ponderas Academic Hospital since 2013. It is worth mentioning that Ponderas Academic Hospital has a Center of Excellence in Bariatric and Metabolic Surgery, as certified by European Accreditation Council for Bariatric Surgery (EAC-BS) since 2011 and by Surgical Review Corporation since 2013, with an average of 1000 bariatric procedures per year.

The selection criteria for indicating a bariatric procedure for adolescents were: BMI over $30 \mathrm{~kg} / \mathrm{m}^{2}$ with comorbidities, BMI over $35 \mathrm{~kg} / \mathrm{m}^{2}$ with/without comorbidities, after failed nutritional counseling for at least 12 months, bone maturation certified with DXA (dual X-ray absorptiometry), with psychological counseling for the adolescent and its parents/ 
tutors for a full understanding of surgery goals and implications. The exclusion criteria were failure to attend the nutritional counseling, uncontrolled psychiatric disorders, drug or alcohol addiction, pregnancy, oncologic diseases.

The multidisciplinary team evaluates all the patients before and after the surgery. When treating adolescent obesity, pediatric surgeon is added to the team formed by nutritionist, bariatric surgeon, cardiologist, endocrinologist, gastroenterologist, psychologist, and decide the proper intervention according to anthropometric parameters, morbidities and body composition (DXA).

All legal guardians signed the informed consent before the surgery, after being explained the potential risks and benefits of the procedure to be performed, and the need for the adolescent to strictly attend the postoperative follow-up program. The Institutional Review Board approval was obtained for this study.

Follow up consisted of regular visits at 1, 3, 6 and 12 months after surgery and then every year or anytime if necessary. Every visit consists of nutritional evaluation and counseling, upper GI contrast study, abdominal ultrasonography, lab tests and psychological evaluation. Upper endoscopy is performed yearly. Patients who did not show up for their appointments were contacted by phone and asked about anthropometric parameters, symptoms, comorbidities evolution and current medication.

We have analyzed demographic data, preoperatory weight and body mass index, comorbid conditions - hypertension, diabetes, hyperlipidemia, gastroesophageal reflux, obstructive sleep apnea - and their postoperative evolution. We also documented total weight loss and the evolution of BMI. Operative data such as duration of surgery, blood loss, the perioperative and late postoperative complications were analyzed.

\section{Statistical Analysis}

Data was collected and introduced in an Apache OpenOffice Calc database, version 4.1.0 (Copyright 2014 The Apache Software Foundation). Statistical analysis was performed using R program, version 3.1.2 (2014-10-31) Pumpkin Helmet (C) R Core Team (2014). R: A language and environmental for statistical computing R Foundation for Statistical Computing, Vienna, Austria URL http://www.R-project.org/.).

\section{Results}

Between 2013 and November 2019, 64 patients, aged 12 to 18 years, received gastric by-pass $(n=2)$ and laparoscopic sleeve gastrectomy $(n=$ 62). Three patients with sleeve gastrectomy were pre-operatory diagnosed with hiatal hernia and crura approximation was performed during the same operating session.

There were 20 males and 44 females with mean age at surgery of 15 years and 5 months (SD - 18 months). Mean preoperatory weight was $115.7 \mathrm{~kg}$, with mean BMI of $39.5 \mathrm{~kg} / \mathrm{m}^{2}$, (interval $30.3-60.5 \mathrm{~kg} / \mathrm{m}^{2}$, SD 6.87 ) and mean excess weight of $54.34 \mathrm{~kg}$ (SD 20.89).

At the initial evaluation, hypertension defined by systolic blood pressure higher than $140 \mathrm{mmHg}$ and diastolic blood pressure higher than $90 \mathrm{mmHg}$ was identified in 6 patients, glucose intolerance defined by fasting blood glucose between 100 and $125 \mathrm{mg} / \mathrm{dL}$ without medication, was identified in 6 patients and diabetes was identified in 6 patients, ( 2 of them had type 1 diabetes mellitus). Other comorbidities were higher than normal blood cholesterol and triglycerides in 27 patients, fatty liver in 12 patients (ultrasound criteria) and obstructive sleep apnea in 3 patients; gastro-esophageal reflux (GER) was diagnosed (on upper GI contrast study and endoscopy) in 14, 11 of them receiving dedicated medication.

All operations were performed by laparoscopic approach, by the same surgical team, without any conversions, with minimal intraoperative blood loss (fewer than 50 cc/patient), a mean duration of operating time of 58 minutes (interval 45-150 min), with no major perioperative complication and no mortality. Most patients were discharged at home after 3 days (mean length of hospital stay of 3.2 days, interval 2-14 days). There was a patient with a 14 days hospitalization for prolonged dysphagia after sleeve gastrectomy, where the nasogastric 
Table 1. Change in weight in follow-up intervals

\begin{tabular}{lccccc}
\hline & \multicolumn{5}{c}{ Follow-up interval } \\
\hline & Pre operatory 64/64 & \multicolumn{5}{c}{ Postoperative } \\
\hline & & one month & $\mathbf{3}$ months & $\mathbf{6}$ months & 1 year \\
& $\mathbf{6 1 / 6 4}$ & $\mathbf{5 6 / 6 4}$ & $\mathbf{5 0 / 6 4}$ & $\mathbf{4 6 / 6 4}$ \\
\hline Mean weight & $115.72 \mathrm{~kg}$ & $100.98 \mathrm{~kg}$ & $88.83 \mathrm{~kg}$ & $80.30 \mathrm{~kg}$ & $\mathbf{7 3 . 6 2 \mathrm { kg }}$ \\
\hline Mean BMI & $39.5 \mathrm{~kg} / \mathrm{m}^{2}$ & $34.4 \mathrm{~kg} / \mathrm{m}^{2}$ & 30.32 & 26.93 & 24.92 \\
\hline Mean weight loss & 0 & $13.6 \mathrm{~kg}$ & $13 \mathrm{~kg}$ & $33 \mathrm{~kg}$ & $41.5 \mathrm{~kg}$ \\
& 0 & $(7-59 \mathrm{~kg})$ & $(15-66 \mathrm{~kg})$ & $(17-88 \mathrm{~kg})$ & $(18-90 \mathrm{~kg})$ \\
\hline \% from BMI & 0 & $-12.9 \%$ & $-23.24 \%$ & $-31.82 \%$ & $-36.9 \%$ \\
\hline \%weight loss & & $-12.73 \%$ & $-23.23 \%$ & $-30.60 \%$ & $-36.38 \%$ \\
\hline
\end{tabular}

BMI- body mass index, *\% from BMI - change form base line (preoperatory), **\%weight loss - change from base line

(NG) tube was maintained 11 PODs.

Of the sixty-four operated patients, 3 were lost from follow up from the beginning, for the other 61 The mean follow-up period was 26 months.

One month after surgery, the mean weight loss was of $13.6 \mathrm{~kg}$ (interval $7-59 \mathrm{~kg}$ ), 24,13 $\mathrm{kg}(15-66 \mathrm{~kg})$ at 3 months, $33 \mathrm{~kg}(17-88 \mathrm{~kg})$ at 6 moths and $41.5 \mathrm{~kg}(18-90 \mathrm{~kg})$ at 1 year.

In terms of BMI, the initial mean value of $39.5 \mathrm{~kg} / \mathrm{m}^{2}$ decreased to $34.4 \mathrm{~kg} / \mathrm{m}^{2}$ one month after surgery, to 30.32 at 3 months, 26.93 at 6 months and 24.92 at 12 months (Table 1).

The BMI at $36 \mathrm{PO}$ months was $22.7 \mathrm{~kg} / \mathrm{m}^{2}$. For the few patients (5/64) we could follow-up , more than 5 years after surgery, we observed that they did not lose any more weight, on the contrary some of them gained a few kilograms $(3-6.5 \mathrm{~kg})$ due to the physiological growth and maintaining the BMI in the normal range.

Resolution of comorbidities was encountered in all the patients after bariatric surgery (see Table 2): hypertension resolved (6/6), with arterial blood pressure falling within the normal range, without medication in all 6 patients; glucose intolerance resolved within one month in all patients (6/6) while diabetes remised in 4/6 patients and persisted in those 2 patients who had type $1 \mathrm{DM}$, lower doses of insulin were needed for a better glycemic control (HbA1c $<6.4 \%$ at 12 PO months). Hyperlipidemia gradually resolved in most of the patients $(24 / 27)$ within 2 years while those with obstructive sleep apnea syndrome described disappearance of symptoms after 3 months.
Gastroesophageal reflux had an interesting evolution in the postoperative period. Before surgery, we identified 14 patients that had gastroesophageal reflux based on symptoms and or pre operatory evaluation. Of these, 11 of them received dedicated medication for the control of their symptoms. After surgery, of those taking antireflux medication before, 5 (5/11) continued to need it and 6 still had minor symptoms but did not need to continue with medication. The 3 patients that had minor symptoms of GERD before, continued to have minor symptoms after and did not need medication. There were also 2 patients who developed GERD after sleeve gastrectomy and needed medication to control their symptoms 6 months and 1 year after surgery, respectively.

Other reported problems among operated patients were controlled by vitamin, mineral and protein supplementation : iron deficiency related to anemia (6/61) resolved in all cases

Table 2. Prevalence of comorbidity and postoperative resolution

\begin{tabular}{|c|c|c|}
\hline Type of comorbidity & preoperatory & postoperative resolution \\
\hline \multicolumn{3}{|l|}{ Major comorbidity } \\
\hline $\mathrm{HT}$ & $6 / 61$ & $6 / 6(100 \%)$ \\
\hline DM & $6 / 61$ & $4 / 6(66.66 \%)$ \\
\hline Glucose intolerance & $6 / 61$ & $6 / 6(100 \%)$ \\
\hline Hyperlipidemia & $27 / 61$ & $24 / 27(88.88 \%)$ \\
\hline GER & $14 / 61$ & $9 / 14(64.28 \%)$ \\
\hline OSAS & $3 / 61$ & $3 / 3(100 \%)$ \\
\hline Fatty liver & $12 / 61$ & $12 / 12(100 \%)$ \\
\hline
\end{tabular}

HT- hypertension, DM diabetes mellitus, GER gastroesophageal reflux, OASA obstructive sleep apnea syndrome 
Table 3. Late postoperative complications

\begin{tabular}{lc}
\hline Type of postoperative complication & prevalence \\
\hline Minor & \\
\hline Constipation & $22 / 61(36.06 \%)$ \\
\hline Iron deficiency related anemia & $6 / 61(9.83 \%)$ \\
\hline Folate deficiency & $4 / 61(6.55 \%)$ \\
\hline Temporary excessive hair loss & $12 / 61(19.67 \%)$ \\
\hline
\end{tabular}

after 12 PO months, folate deficiency (5/61) resolved in $3 / 5$ patients at $12 \mathrm{PO}$ months, constipation (22/61) and temporary hair falling (12/61).

Although all patient received prophylactic doses of Ursodezoxicolic acid for 6 months postoperatively, two patients required laparoscopic cholecystectomy for acute cholecystitis (gallstones up to $5 \mathrm{~mm}$ ) one year after sleeve gastrectomy (11 and 14 months).

In the study group there was no early or late postoperative mortality.

\section{Discussions}

Although in Romania, a guide for the management of obese adolescents who fail intensive medical management is lacking, as mentioned before, international guides and consensus letters are now available.

Recently the Pediatric Committee of The American Society of Metabolic and Bariatric Surgery (ASMBS) and other medical societies like The Italian Society for Pediatric Endocrinology and Diabetology published guidelines and consensus papers trying to establish the role of bariatric surgery in the management of adolescent and pediatric obesity $(13 ; 11)(15)$. In ASMBS guidelines published in 2018 it is recognized that metabolic and bariatric surgery is a proven, effective treatment for severe obesity disease in adolescents and should be considered standard of care. Moreover, they say that the presence of cardiovascular disease factors like hyperlipidemia, elevated inflammatory markers, hypertension and insulin resistance should be considered a strong indicator for metabolic and bariatric surgery in adolescents with obesity.

In our study we also included adolescents with a body mass index below $35 \mathrm{~kg} / \mathrm{m}^{2}$ and associated comorbidities. This allowed us to observe that in all patients with stage I obesity (BMI 30-34.9 kg/m²), loosing the excess body weight through bariatric surgery removed the cardiovascular disease risk factors (type 2 diabetes, hyperlipidemia, nonalcohol fatty liver disease) and this creates a strong premise for early intervention even in these patients with a low BMI. The early remission of cardiovascular disease risk factors helps this category of patients avoid the serious and known complications of metabolic syndrome, including decreased life quality and increased mortality.

Timing of metabolic and bariatric surgery in very important and should be carefully chosen for each individual patient. Besides medical criteria, like the BMI score and the presence of comorbidities, psychological burden is very important. The psychological evaluation should be thorough and take into account the patient, his/her parents or caregivers and his/her entire social environment. Total and correct motivation of the patient and their caregivers, support from the close family members and realistic expectations are all mandatory criteria, as they are crucial for best results.

Observing the gastric sleeve patients' evolution to a normal range of BMI in a short period of time, we agree with other studies available and say sleeve gastrectomy seems efficient and safe and can be used in the management of adolescent morbidity (16).

In their study, Salman K. Al-Sabah analyzed the data of 135 patients with morbid obesity (mean BMI $48.5 \mathrm{~kg} / \mathrm{m}^{2}$ ) who received sleeve gastrectomy and found that most of the patients lost more than $50 \%$ of excess weight in the first 6 months and more than $70 \%$ by 1 year, while comorbidities resolved in most of the patients (5/5 cases of diabetes mellitus and $3 / 4$ cases with hypertension) by 2 years postoperatively. These results are similar to what we observed in ours.

In another study (17) Lainas Panagiotis also agreed on the safety and effectiveness of sleeve gastrectomy as an option of treatment in adolescent obesity. They analyzed the 
information available of 84 adolescent patients who underwent sleeve gastrectomy and found that the initial mean BMI decreased form $43.7 \mathrm{~kg} / \mathrm{m}^{2}$ to $28.8 \mathrm{~kg} / \mathrm{m}^{2}$ by 24 months, with improvement of comorbidities by 1 year and only one significant perioperative complication - pneumonia that needed prolonged intravenous antibiotics in one patient.

All these studies, including ours, confirm the safety and efficacy of sleeve gastrectomy in treating obesity in adolescents at least on a short and medium term. Beside this evidence longer-term follow-up is necessary to see how will these adolescents transition to adult life, if they will maintain a body mass index in the normal range and if other serious complications will occur.

Bariatric and metabolic surgery procedures that were indicated in adolescents with obesity changed over the years. Initially standard procedures were considered to be Roux en Y gastric bypass (RYGB) and adjustable gastric banding (AGB) but as shown in the comparative study of Thomas $\mathrm{H}$ Inge et all, from 2018, based on The National Patient Centered Clinical Research Network in the United States, only RYGB and sleeve gastrectomy have similar good results in decreasing BMI in patients wi-th obesity, while AGB only generates moderate weight loss. Their cohort consisted of 544 adolescents aged 12 to 19 years: 306 received sleeve gastrectomy, 177 RYGB and 61 AGB. All these patients had comparable mean BMI scores before the surgery while at one year after surgery mean BMI decreased with $31.4 \%$ in those with RYGB, $28 \%$ in those with sleeve gastrectomy and only $10 \%$. When adding to this data the facts that gastric sleeve resection is less prone to nutritional deficiencies and has less surgical risk (no anastomosis to promote strictures or leaks) compared to RYGB, it becomes understandable why SG has gained popularity as a metabolic and bariatric surgery procedure.

Even in earlier studies like the one that Cozacov published in 2014, show the comparable efficiency of RYGB and sleeve gastrectomy in enabling weight loss in adolescents with obesity with similar rates of comorbidity resolution. The author's preference for sleeve gastrectomy seems motivated by the simplicity of the surgical procedure - absence of anastomosis, the restrictive component that comes with serious stomach volume reduction and the hormonal down regulation of hunger hormones induced by stomach partial resection, that results in a long-term reduction of hunger feeling (18).

Considering the results of all these studies, the most delicate point in the management of adolescent patients with obesity, which is timing, seems to become more evident. When we try to answer the question: is it better to wait for the patient's physical and psychological maturation before proceeding to bariatric surgery or should we do it earlier, before progression of cardiovascular disease risk factors or end organ irreversible damage due to metabolic syndrome complications? - the balance tilts towards earlier intervention.

In regard to the preferred bariatric surgery procedure, we can say that laparoscopic sleeve gastrectomy found a central position in the surgical therapeutic arsenal, due to its multiple advantages that most bariatric surgeons are already aware of.

As evident in many papers already published, obese children seem to be best managed in experience centers (Centers of Excellence in Metabolic and Bariatric Surgery) were a multidisciplinary team is available. Besides the fact that medical specialist provide care for pre- and post-operative complications of obesity (nutritionist, endocrinologist, psychologist, gastroenterologist, etc) general surgeon enables the adolescent to benefit from the years of experience gained in adult bariatric and metabolic surgery while pediatric surgery covers the specific area of pediatric surgery. Moreover, the transition of care is very smooth, and may help prolong follow up of these patients (19).

The limitations of our study are the relatively small number of patients and its retrospective manner. These results should be further confirmed by prospective randomized controlled trials.

The strength of our study is that patients 
were operated in a single center of excellence in bariatric surgery, by the same team.

\section{Conclusions}

Bariatric surgery is already an important part of the management of adolescents with obesity. Among techniques available, laparoscopic sleeve gastrectomy proves to be, again and again, a procedure with lower risks and multiple advantages. Like with every surgical procedure, even lower risks appear when patients are managed in centers of excellence, where multidisciplinary team, with pediatrician and pediatric surgeon included, addresses the patient as a whole and collaborates for best results, in the best interest of the patient.

Analyzing how comorbidities and excess body weight regressed after surgery in the patients included in our study, we postulate that earlier intervention, could bring even more benefit, in terms of earlier resolution of metabolic syndrome and preventing irreversible end organ damage.

A prospective randomized controlled trial would be ideal to confirm this firsts results, and a longer term fallow up could reveal post operative complications that we could not observe in this study (growth impairment, weight gain rebound).

\section{Conflict of Interest}

The authors declare no conflicts of interests.

\section{Author's Contributions}

All authors contributed equally to the manuscript.

\section{References}

1. World Health Organization, Food and Agriculture Organization of the United Nations. Diet, nutrition and the prevention of chronic diseases Report of a joint WHO/FAO expert consultation (WHO Technical Report Series 916). WHO. 2003.

2. Upadahyay J, Farr O, Perakakis N, Ghaly W, Mantzoros C. Obesity as a disease. Med Clin North Am. 2018;102(1):13-33.

3. Centrul National de Evaluare si Promovare a Starii de sanatate. http://insp.gov.ro/sites/cnepss/date-statistice-obezitate/. [Online] http://insp.gov.ro/sites/cnepss/date-statistice-obezitate/.

4. Association of European Cancer Leagues. http://www.preventobesity.eu/. [Online]

5. GBD 2015 Obesity Collaborators, Afshin A, Forouzanfar MH, Reitsma MB, Sur P, Estep K, Lee A, et al. Health effects of overweight and obesity in 195 countries over 25 Years. N Engl J Med. 2017;377 (1):13-27.

6. Peña AS, Delko T, Couper R, Sutton K, Kritas S, Omari T, et al. Laparoscopic adjustable gastric banding in Australian adolescents: should it be done? Obes Surg. 2017;27(7):1667-1673.

7. Cummins CB, Lopez ON, Hughes BD, Adhikari D, Guidry CA, Stubbs S, et al. Adolescent bariatric surgery: effects of socioeconomic, demographic and hospital characteristics on cost, length of stay, and type of rocedure performed. Obes Surg. 2019; 29(3):757-764.

8. Beamish AJ, Reinehr T. Should bariatric surgery be performed in adolescents? Eur J Endocrinol. 2017;176(4):D1-D15.

9. Fennig U, Snir A, Halifa-Kurzman I, Sela A, Hadas A, Fennig S. Presurgical weight loss predicts post-surgical weight loss trajectories in adolescents enrolled in a bariatric porgramme. Obes Surg. 2019;29(4):1154-1163.

10. Inge TH, Yates Coley R, Bazzano LA, Xanthakos SA, McTigue K, Arterburn D, et al. Comparative effectiveness of bariatric procedures among adolescents: the PCORnet bariatric study. Surg Obes Relat Dis. 2018;14(9):1374-1386.

11. Vilallonga R, Moreno Villares JM, Yeste Fernández D, Sánchez Santos R, Casanueva Freijo F, Santolaya Ochando F, et al. Initial approach to childhood obesity in spain. A multisociety expert panel assessment. Obes Surg. 2017; 27(4):997-1006.

12. Khidir N, El-Matbouly MA, Sargsyan D, Al-Kuwari M, Bashah M, Gagner M. Five-year outcomes of laparoscopic sleeve gastrectomy: a comparison between adults and adolescents. Obes Surg. 2018; 28(7):2040-2045

13. Valerio G, Maffeis C, Saggese G, Ambruzzi MA, Balsamo A, Bellone $S$, et al. Diagnosis, treatment and prevention of pediatric obesity: consensu position statement of the Italian Society for Pediatric Endocrinology and Diabetology and the Italian Society of Pediatrics. Ital J Pediatr. 2018;44(1):88.

14. Styne DM, Arslanian SA, Connor EL, Sadaf Faroogi I, Hassan Murad M, Silverstein $\mathrm{JH}$, et al. Pediatric obesity-assessment, treatment, and prevention: An Endocrine Society Clinical Practice Guideline. J Clin Endocrinol Metab. 2017;102(3):709-757.

15. Pratt JSA, Browne A, Browne NT, Bruzoni M, Cohen M, Desai A, et al. ASMBS pediatric metabolic and bariatric surgeryguidelines. Surg Obes Relat Dis. 2018;14(7):882-901.

16. Al-Sabah SK, Almazeedi SM, Dashti SA, Al-Mulla AY, AlMohammad Ali D, Jumaa TH, et al. The efficacy of laparoscopic sleeve gastrectomy in treating adolescent obesity. Obes Surg. 2015;25(1), 50-4.

17. Lainas P, De Filippo G, Di Giuro G, Mikhael R, Bougneres P, Dagher I. Laparoscopic sleeve gastrectomy for adolescents under 18 years old with severe obesity. Obes Surg. 2019 Sep 13[Online ahead of print].

18. Cozacov Y, Roy M, Moon S, Marin P, Lo Menzo E, Szomstein S, et al. Mid-term Results of Laparoscopic Sleeve Gastrectomy and Roux-en-Y Gastric Bypass in Adolescent Patients. Obes Surg. 2014;24(5):747-52.

19. Cairo SB, Majumdar I, Pryor A, Posner A, Harmon CM, Rothstein DH. Delivery of Surgical Care Committee of the American Academy of Pediatrics Section on Surgery Challenges in transition of care for pediatric patienst after weight reduction surgery: a systematic review and recommendations for comprehensive care. Obes Surg. 2018;28 (4):1149-1174. 